\title{
Life on a limb: ecology of the tree agama (Acanthocercus a. atricollis) in southern Africa
}

\author{
Leeann T. Reaney and Martin J. Whiting* \\ Communication and Behaviour Research Group, School of Animal, Plant and Environmental Sciences, University of the Witwatersrand,
} Private Bag 3, Wits 2050, South Africa

(Accepted 9 August 2001)

\begin{abstract}
One hundred and sixty-four museum specimens of the tree agama Acanthocercus a. atricollis were measured and dissected to examine sexual size dimorphism, reproduction and diet. Foraging mode and behaviour were also quantified in a wild population to obtain a broader picture of their foraging ecology and to test the hypothesis that tree agamas are ambush foragers. Males and females did not differ significantly in snout-vent length (SVL) or tail length; however, mature males had larger heads than females of the same body size. The smallest female showing sexual maturity was $96 \mathrm{~mm} \mathrm{SVL}$ and the smallest male was $82 \mathrm{~mm}$ SVL. Mean clutch size was 11.3 and was positively correlated with female body size. Reproduction was seasonal and male and female reproductive cycles were synchronous. Testicular volume was greatest during August-September and females contained enlarged follicles during August-December and showed no evidence of multiple clutching. Tree agamas fed on a broad spectrum of arthropods (10 orders), including millipedes, which other lizard taxa have been reported to avoid. Gut contents were dominated numerically by ants $(92 \%)$, followed by beetles $(4 \%)$. Volumetrically, orthopterans $(26.8 \%)$ were most important, followed by beetles $(26.3 \%)$ and ants $(17.9 \%)$. Compared to adults, juvenile diet by volume was dominated by ants and consisted of fewer large prey items (e.g. beetles and orthopterans). Seasonal effects in both prey diversity and volume were evident. Tree agamas are classic ambush foragers. They spent only $4 \%$ of their time moving and made few movements per minute (mean $=0.4$ ). When stationary, adult tree agamas positioned themselves on tree trunks (34.7\%), on lateral branches $(41.8 \%)$ and occasionally, on the ground $(23.4 \%)$. No evidence of trophic partitioning (intraspecific niche divergence hypothesis) was found and field observations revealed that males defend territories and engage in combat. This supports the idea that selection may be favouring larger head size in males, as an outcome of male contest competition.
\end{abstract}

Key words: sexual size dimorphism, intraspecific niche divergence hypothesis, male contest competition, reproduction, diet, foraging mode, Acanthocercus a. atricollis

\section{INTRODUCTION}

Lizards have long been recognized as organisms highly amenable to ecological study (Milstead, 1967; Huey, Pianka \& Schoener, 1983; Vitt \& Pianka, 1994) and useful for testing ecological and evolutionary theory (e.g. Sinervo \& Huey, 1990; Sinervo \& Licht, 1991; Losos, Warheit \& Schoener, 1997; Losos, Jackman et al., 1998). Frequently, ecological and evolutionary patterns and theory are drawn from studies of many different taxa from disparate areas (e.g. Pianka, 1986). However, ecological studies of lizards are strongly biased towards North American, Australian, Carribean,

*All correspondence to: M. J. Whiting.

E-mail: martin@gecko.biol.wits.ac.za and more recently, Neotropical taxa (e.g. Vitt \& Caldwell, 1994; Vitt, 1995; Vitt \& Zani, 1996). The ecology and natural history of African lizards remains poorly known (but see Pianka, 1986; Van Wyk, 1992; Mouton \& Van Wyk, 1997) and represents a void in the study of life-history patterns and the relative influence of phylogeny and ecology on the evolution of organismal traits. African lizards show strong ecological convergence with their counterparts from other continents and predictions and theories generated from these studies can be readily applied to African taxa.

For example, insectivorous lizards typically fall into two foraging modes: ambush and active. The type of foraging mode adopted has been shown to correlate with a host of co-evolved traits (Huey \& Pianka, 1981). Active foragers tend to have higher metabolic rates 
(Anderson \& Karasov, 1981), low relative clutch mass (Huey \& Pianka, 1981), and slender morphology (Losos, 1990) when compared to most ambush foragers. Active foragers are also more vulnerable to ambush predators and use speed as a primary defence, whereas ambush foragers rely more on crypsis (Cooper, Vitt et $a l ., 1990)$. These patterns appear to hold independently of phylogenetic history and therefore allow basic predictions about foraging mode to be made based on little information (for example morphology).

Tree agamas Acanthocercus a. atricollis are large (largest snout-vent length (SVL): $167 \mathrm{~mm}$ ), diurnal, arboreal lizards that are sexually dichromatic. Mature males have a bright blue head and throat and a broad yellow-green vertebral stripe; females are olive-coloured with black marbling. Males are aggressive and reported to be larger than females (Branch, 1998). They occur throughout Africa, ranging from Ethiopia in the north to coastal KwaZulu-Natal, South Africa, in the south (Branch, 1998). Although aspects of the ecology of other agamas have been reported in some detail (e.g. Van Wyk, 1983, 1984a,b; Waltner, 1991; Heideman, 1994; Cooper, Whiting, van Wyk \& Mouton, 1999; Flemming \& Mouton, 2000), the ecology and life history of $A$. a. atricollis is poorly known, except for anecdotal observations.

The objective of this study was to describe the ecology of $A$. a. atricollis in southern Africa, with particular reference to sexual dimorphism, reproduction, and diet, using museum specimens. In addition, we collected field data on foraging behaviour to obtain a broader picture of tree agama foraging ecology and behaviour and to test the hypothesis that tree agamas are ambush foragers. This hypothesis is based on their tank-like morphology and data showing that other agamas are ambush foragers (Cooper, Whiting, van Wyk \& Mouton, 1999). Finally, after verifying sexual dimorphism in head size, we explore two explanations for the evolution of large head size in males: intraspecific niche divergence and sexual selection through male contest competition.

\section{MATERIALS AND METHODS}

\section{Sexual size dimorphism and reproduction}

Preserved $A$. a. atricollis were measured for SVL and tail length with a ruler to the nearest $\mathrm{mm}$. Tails were also scored as complete or broken. Head length (HL) was measured from the tip of the snout to the anterior end of the typanum. Head width (HW) was measured at the widest point of the head, in the region of the occiput. Both head length and width were measured with digital callipers to the nearest $0.01 \mathrm{~mm}$. In juveniles, sex was verified by dissection. Before testing for differences in sexual dimorphism, the effects of body size were removed by regressing the natural log (base 10) of HL, HW and tail length on log SVL (Vitt, Zani et al., 1993). The residuals from each regression were then subjected to ANOVA with sex as the independent factor. Equality of variance was first tested for using Bartlett's tests. The residuals from the regression of log tail length on $\log$ SVL violated the assumption of equal variance $\left(\chi_{1}^{2}=12.83, P=0.0003\right)$, we therefore used a Kruskal-Wallis test. Sexual differences in SVL were tested for using a $t$-test for unequal variance (Analytical Software, 1996).

Females were considered sexually mature if they contained oviductal eggs or enlarged vitellogenic follicles or a convoluted oviduct. For gravid females, oviductal eggs were counted and the size (length and width) of the largest egg was measured to the nearest $0.01 \mathrm{~mm}$ using digital callipers. Oviductal egg volume was calculated using the formula for a prolate spheroid (Vitt, Zani et al., 1993):

$$
\text { volume }=4 / 3 \pi(\text { length } / 2) *(\text { width } / 2)^{2} .
$$

Males were considered sexually mature if they simultaneously contained enlarged testes and convoluted epididymides. Right testes were measured for length and width to the nearest $0.01 \mathrm{~mm}$, and volume was determined using the formula for a prolate spheroid (as before).

\section{Diet}

Each specimen was opened using a mid-ventral incision. Diet was determined following removal of the stomach and alimentary canal. All prey items were spread in a Petri dish and identified to order and, if possible, to family. Some dominant prey (ants) were identified to species. Complete prey items were measured for length and width with digital callipers $( \pm 0.01 \mathrm{~mm})$. Volume for each individual prey item was calculated using the formula for a prolate spheroid (above). The reciprocal of Simpson's (1949) diversity measure was used to estimate niche breadth:

$$
B=1 \sum_{i=1}^{n} p^{2}
$$

where $i$ is the resource category, $p$ is the proportion of resource category $i$, and $n$ is the total number of categories. Values vary from 1 (exclusive use of 1 prey type) to $n$ (even use of all prey types). Prey categories consisted of the arthropod orders of prey items found in the gut contents.

\section{Foraging mode and behaviour}

Foraging mode was determined for a population of A. a. atricollis in Mountain Sanctuary Park $\left(25^{\circ} 50^{\prime} \mathrm{S}\right.$, $27^{\circ} 28^{\prime}$ E), Magaliesberg, North-West Province, South Africa, during September to mid-November 2000. The study area is a campground on a north-facing slope of the Magaliesberg Mountains, a continuous ridge 
running from Rustenburg in the west to Pretoria in the east. Apart from grass and small shrubs, the site consists of mainly thorn trees Acacia sp., buffalo thorns Ziziphus mucronata, common resin trees Ozoroa paniculosa, mountain karree Rhus leptodictya and wild seringa Burkea africanas. Ground cover (mostly grass) is kept short for camping purposes.

Ambush and active foragers can be distinguished using the relative amount of time spent in motion while foraging (Cooper, Whiting, van Wyk \& Mouton, 1999). To determine foraging mode, 2 variables are generally measured: the number of moves per minute (MPM) and the percent time spent moving (PTM), although the dividing line between active and ambush MPM and PTM are generally determined arbitrarily (Cooper, Whiting \& van Wyk, 1997). Perry's (1995) in Cooper, Whiting \& van Wyk (1997) criterion of PTM $=10$ to separate ambush and active foraging is used here. Foraging mode was quantified by performing 15-min continuous focal observations on lizards that had been previously caught and marked with coloured collars for individual identification. Prey capture attempts and movements $>10 \mathrm{~cm}$ were noted. Observations were made during 09:00 and 16:00, recorded on a dictaphone and later transcribed. If a lizard seemed to have been disturbed, its behaviour was not recorded at that time. Time spent on social interactions and when a lizard was out of view was subtracted from total sampling time. All focals lasted at least $270 \mathrm{~s}$ and had a mean duration of $821.36 \mathrm{~s}( \pm 32.75,1 \mathrm{sE})$. Of the 44 focal samples, $80 \%$ $(n=36)$ were for the full duration. The number of moves per minute (MPM) and percent time spent moving (PTM) were then calculated. The assumptions of homogenous variances and normal distribution in MPM and PTM data could not be met, and therefore MannWhitney tests were used for differences in MPM and PTM between the sexes. Mann-Whitney $U$-tests were also used to test for differences in prey capture attempt rates between the sexes.

Having determined that tree agamas are ambush foragers, the amount of time spent stationary in 3 different microhabitats was quantified: on the ground, on the main trunk, and on lateral branches. When on main trunks, the lizard's position (facing up, down or horizontal) was also recorded. Because of small sample sizes and 0 values, comparisons were made within and between sexes using Mann-Whitney tests (applying the normal approximation for continuity correction (Analytical Software, 1996)) and Kruskal-Wallis tests.

All means are reported $\pm 1 \mathrm{SE}$ and differences were considered significant at $\alpha<0.05$.

\section{RESULTS}

\section{Sexual dimorphism and reproduction}

The largest male had an $\mathrm{SVL}=155 \mathrm{~mm}$, while the largest SVL for a female was $144 \mathrm{~mm}$. However, there was no significant difference in mean SVL between
Table 1. Descriptive statistics (mean $\pm \mathrm{SE}$ ) of morphological measurements for adult male and female Acanthocercus a. atricollis. Ranges are shown in parentheses. All measurements in $\mathrm{mm}$

\begin{tabular}{lll}
\hline & $\begin{array}{l}\text { Males } \\
(n=65)\end{array}$ & $\begin{array}{l}\text { Females } \\
(n=53)\end{array}$ \\
\hline Snout-vent length & $117.22 \pm 2.47$ & $\begin{array}{l}117.02 \pm 1.74 \\
(96-144)\end{array}$ \\
& $(82-155)$ & $144.01 \pm 3.08$ \\
Tail length & $160.48 \pm 3.55$ & $(101-185)$ \\
& $(118-218)$ & $27.04 \pm 0.35$ \\
Head length & $28.71 \pm 0.61$ & $(22.30-32.12)$ \\
& $(20.19-38.65)$ & $29.63 \pm 0.48$ \\
Head width & $35.12 \pm 0.93$ & $(21.88-38.59)$ \\
\hline
\end{tabular}
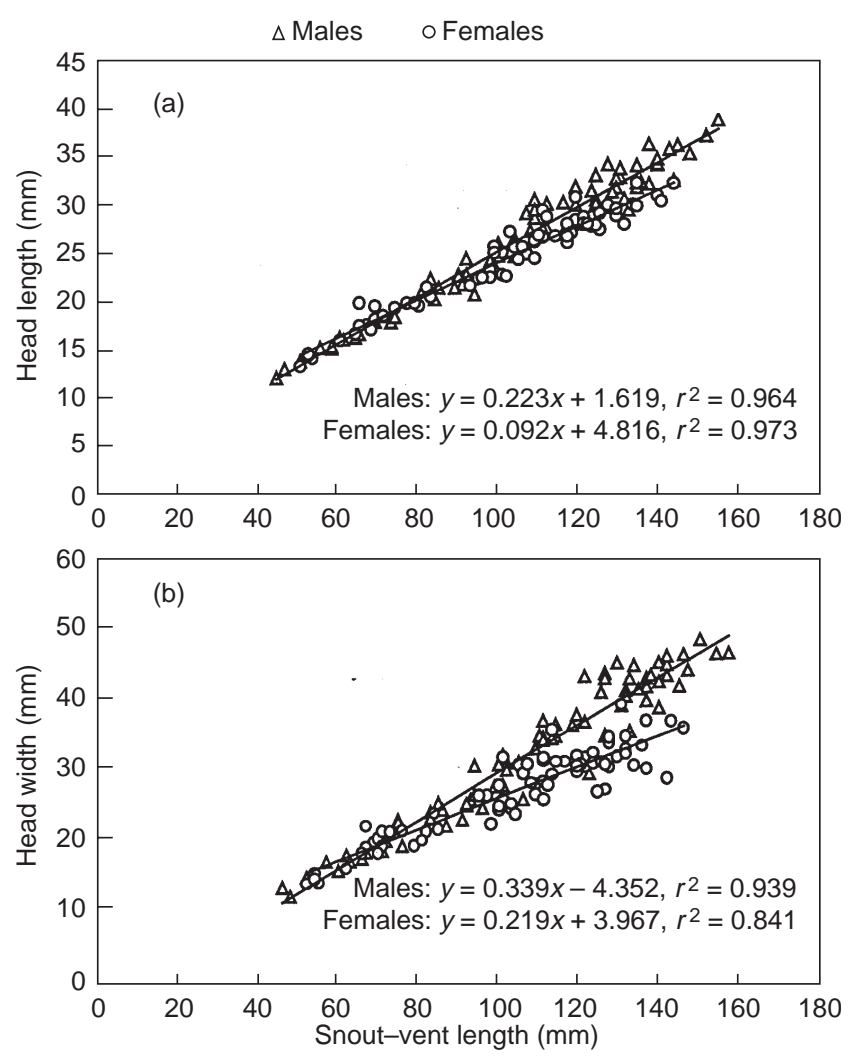

Fig. 1. Relationship between head length (a) and head width (b) and snout-vent length for male and female Acanthocercus a. atricollis.

mature males and females $\left(t_{102.5}=0.23, \quad P=0.82\right.$; Table 1). When the influence of body size was removed, males had both wider (equal variance, $\chi_{1}^{2}=1.41$, $P=0.23 ; F_{1,114}=105.3, P<0.0001$ ) and longer (equal variance, $\left.\chi_{1}^{2}=0.30, P=0.58 ; F_{1,114}=49.96, P<0.0001\right)$ heads than females (Table 1, Fig. 1a, b). Male and female tail length (only complete tails) was not significantly different when the influence of body size was removed $(H=1.452, P=0.23$; Table 1$)$.

The smallest sexually mature female was $96 \mathrm{~mm}$ SVL. Clutch size ( $n=23$ females) averaged 11.36 \pm 0.05 (Fig. 2a), while mean egg volume of the largest follicle was $1251.71 \pm 141.13 \mathrm{~mm}^{3}$ (Fig. 2b). There was a positive correlation between female SVL and clutch size 

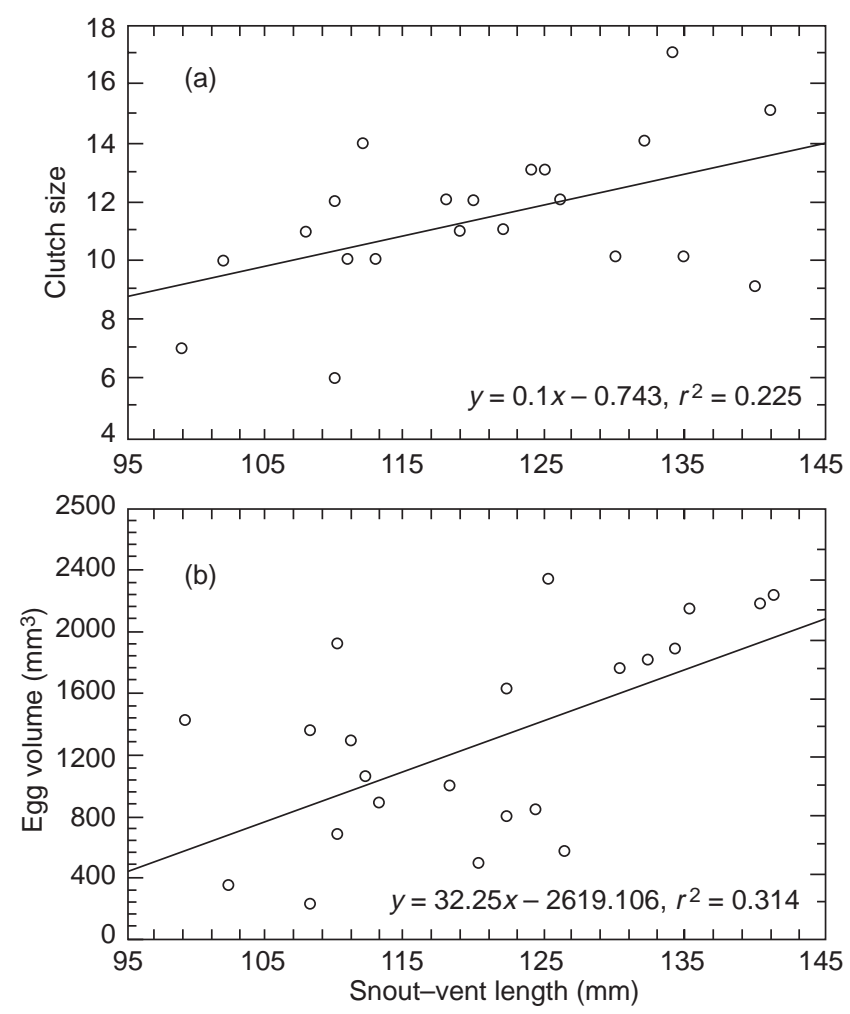

Fig. 2. Relationship between female clutch size (a) and egg volume (b) and snout-vent length for Acanthocercus a. atricollis.

$\left(r^{2}=0.225, F_{1,20}=5.83, P=0.025\right.$; Fig. $\left.2 \mathrm{a}\right)$ and SVL and egg volume ( $r^{2}=0.314, F_{1,21}=9.61, P=0.005$; Fig. $\left.2 b\right)$. Seasonal variation in ovarian volume of the largest follicle indicated that females were gravid from August to December (Fig. 3a). A single female from Mozambique had enlarged follicles when it was collected in July (Fig. 3a). There was no evidence of multiple clutches in the specimens examined.

The smallest sexually mature male was $82 \mathrm{~mm}$ SVL. Testicular volume increased positively with SVL $\left(r^{2}=0.358, F_{1,68}=38.036, P<0.0001\right)$ and testes were most turgid during August-September (spring), gradually tapering off during November-December (summer; Fig. 3b). Male and female reproductive cycles are therefore synchronous.

\section{Diet}

There was no significant correlation between gape size and mean prey volume $\left(r^{2}=0.005, \quad F_{1,141}=0.768\right.$, $P=0.382)$, or between SVL and mean prey volume $\left(r^{2}=0.028, F_{1,140}=4.134, P=0.044\right)$. Similarly, there was no significant correlation between the largest single prey item consumed $\left(\mathrm{mm}^{3}\right)$ and gape size $\left(r^{2}=0.021\right.$, $\left.F_{1,141}=3.029, P=0.084\right)$, and largest single prey item consumed and SVL $\quad\left(r^{2}=0.039, \quad F_{1,140}=4.361\right.$, $P=0.039)$.

Ten categories of arthropods were found in the gut of
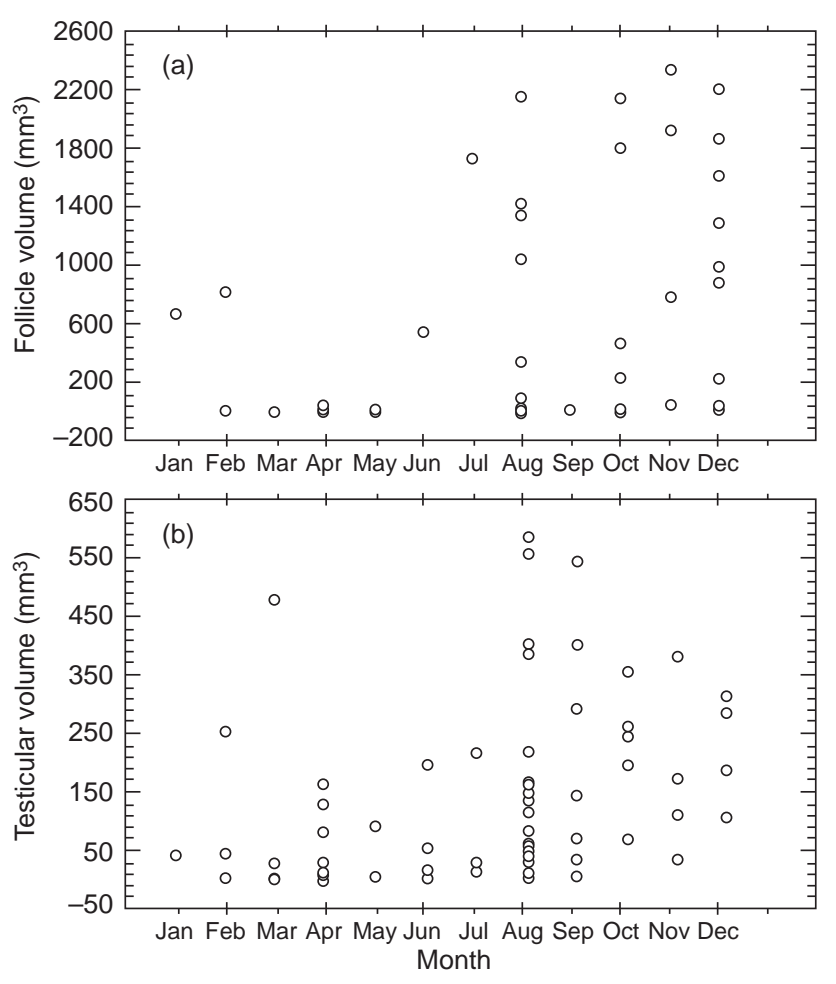

Fig. 3. Female follicle volume and male testicular volume of Acanthocercus a. atricollis in relation to time of the year.

A. a. atricollis (Table 2). Diet was dominated numerically by ants $(92 \%)$, followed by beetles $(4 \%)$. Volumetrically, orthopterans (grasshoppers and crickets) were the most important component of the diet $(26.8 \%)$, followed by beetles $(26.3 \%)$ and ants $(20.9 \%)$. Niche breadth for prey number was 2.21, indicating many individuals of just a few prey types (Hymenoptera and Coleoptera). Niche breadth for prey volumes was 4.32, suggesting that several prey categories contributed to prey volume. There was no significant variation in diet between males, females and juveniles in relation to number of prey items consumed, with Hymenoptera making up $>92 \%$ of the diet in all three groups (Table 3). Volumetrically, orthopterans, beetles and ants were the most important component in the diets of males, females and juveniles (Table 3).

There was no significant difference in the volume of Hymenoptera $\left(\chi_{2}^{2}=4.075, \quad P=0.130\right)$, and beetles $\left(\chi_{2}^{2}=2.874, P=0.238\right)$ found in the gut contents of male, female and juvenile lizards. Female and juvenile gut contents contained more orthopterans than in the males $\left(\chi_{2}^{2}=6.398, P=0.041\right)$. Numerically, the number of ants eaten by adult and juvenile lizards were very similar $\left(\chi_{2}^{2}=0.107, P<0.95\right)$, but juveniles ate significantly fewer beetles $\left(\chi_{2}^{2}=9.413, \quad P<0.009\right)$ and orthopterans $\left(\chi_{2}^{2}=5.669, P=0.059\right)$ than adult lizards (see Table 3).

There was a seasonal effect on the volume and number of beetles consumed (sex and age classes combined; volume: $\chi_{3}^{2}=27.61, \quad P<0.00001$; number: 
Table 2. Composition of the diet of Acanthocercus a. atricollis $(n=151)$ in southern Africa. Diet is reported as the total number of prey found in stomachs (No.), the percentage of each prey taxon consumed (No. (\%)), the total volume of each prey taxon (Volume), the percentage volume of each prey taxon consumed (Volume (\%)) and the number of lizards containing a particular prey taxon (Frequency)

\begin{tabular}{|c|c|c|c|c|c|}
\hline Prey type & No. & No. $(\%)$ & Volume $\left(\mathrm{mm}^{3}\right)$ & Volume (\%) & Frequency \\
\hline \multicolumn{6}{|l|}{ Hymenoptera } \\
\hline \multicolumn{6}{|l|}{ Formicidae } \\
\hline Camponotus vesitus & 5396 & 50.32 & 19778.72 & 12.29 & 69 \\
\hline Camponotus cinctellus & 1532 & 14.29 & 8796.36 & 5.47 & 60 \\
\hline Pheidole sp. & 3024 & 28.20 & 42.23 & 0.03 & 26 \\
\hline Apidae & 37 & 0.35 & 3093.20 & 1.92 & 8 \\
\hline Pompilidae & 38 & 0.35 & 2223.76 & 1.38 & 11 \\
\hline \multicolumn{6}{|l|}{ Coleoptera } \\
\hline Curculionidae & 12 & 0.11 & 1567.50 & 0.97 & 12 \\
\hline Tenebrionidae & 3 & 0.03 & - & - & 2 \\
\hline Scarabaeidae (unidentified) & 4 & 0.04 & - & - & 3 \\
\hline Scarabaeinae & 8 & 0.07 & 731.50 & 0.45 & 8 \\
\hline Cetoniinae & 9 & 0.08 & 11756.25 & 7.31 & 6 \\
\hline Cerambycidae & 2 & 0.02 & 141.07 & 0.09 & 1 \\
\hline Melyridae & 4 & 0.04 & - & - & 1 \\
\hline Lycidae & 1 & 0.01 & 125.40 & 0.08 & 1 \\
\hline Meloidae & 3 & 0.03 & - & - & 2 \\
\hline Chrysomelidae & 2 & 0.02 & - & - & 1 \\
\hline Coccinellidae & 7 & 0.07 & 548.62 & 0.34 & 6 \\
\hline Staphylinidae & 10 & 0.09 & 846.45 & 0.53 & 1 \\
\hline Elateridae & 10 & 0.09 & 914.37 & 0.57 & 1 \\
\hline Unidentified & 364 & 3.39 & 26538.43 & 16.49 & 104 \\
\hline \multicolumn{6}{|l|}{ Orthoptera } \\
\hline Caelifera & 16 & 0.15 & 40462.40 & 25.15 & 14 \\
\hline Ensifera & 10 & 0.09 & 2808.43 & 1.75 & 6 \\
\hline \multicolumn{6}{|l|}{ Isoptera } \\
\hline Termitidae & 123 & 1.15 & 12696.75 & 7.89 & 6 \\
\hline \multicolumn{6}{|l|}{ Hemiptera } \\
\hline Pentatomoidae & 1 & 0.01 & - & - & 1 \\
\hline Unidentified & 21 & 0.20 & 8421.32 & 5.23 & 16 \\
\hline \multicolumn{6}{|l|}{ Larvae } \\
\hline Lepidoptera (unidentified) & 62 & 0.58 & 11428.95 & 7.10 & 34 \\
\hline Coleoptera (unidentified) & 9 & 0.08 & 412.22 & 0.26 & 7 \\
\hline Mantodea (unidentified) & 1 & 0.01 & 326.56 & 0.20 & 1 \\
\hline Phasmatodea (unidentfied) & 1 & 0.01 & 326.56 & 0.20 & 1 \\
\hline Chilopoda & 1 & 0.01 & 376.20 & 0.23 & 1 \\
\hline Diplopoda & 11 & 0.10 & 4048.23 & 2.52 & 11 \\
\hline Total & 10722 & 100.00 & 158411.40 & 100.00 & \\
\hline
\end{tabular}

$\left.\chi_{3}^{2}=14.075, P<0.003\right)$, with the highest consumption occurring in spring and the lowest in autumn. Hymenopterans were consumed in greatest volume and number in autumn, while the lowest volume and number was during summer (volume: $\chi_{3}^{2}=12.49$, $P<0.005$; number: $\left.\chi_{3}^{2}=16.84, \quad P<0.0007\right)$. Orthopteran consumption was significantly greatest in autumn and winter and lowest in spring (volume: $\chi^{2}{ }_{3}=35.5$, $P<0.0001$; number: $\chi_{3}^{2}=59.3, P<0.0001$ ) (Fig. 4, Table 4).
During spring (September-November), beetles and ants made up most of the diet by volume. In summer (December-February), volumetric intake of beetles dropped drastically and fewer Hymenoptera were consumed. In autumn (March-May), lizards consumed a diversity of prey, although the intake of hymenopterans and orthopterans increased. In winter (June-August), dietary intake was dominated mainly by beetles and orthopterans, while hymenopterans made up smaller proportions. The amount of orthopterans consumed 
Table 3. Comparison of diet between male, female and juvenile Acanthocercus a. atricollis. Females with a SVL below $96 \mathrm{~mm}$ and males with a SVL below $82 \mathrm{~mm}$ were considered juveniles. Diet is reported as the total number of prey found in stomachs (No.), the percentage of each prey taxon consumed (No. (\%)), the total volume of each prey taxon (Vol.), the percentage volume of each prey taxon consumed (Vol. (\%)) and the number of lizards containing a particular prey taxon (F)

\begin{tabular}{|c|c|c|c|c|c|c|c|c|c|c|c|c|c|c|c|}
\hline \multirow[b]{2}{*}{ Prey category } & \multicolumn{5}{|c|}{ Females $(n=39)$} & \multicolumn{5}{|c|}{ Males $(n=49)$} & \multicolumn{5}{|c|}{ Juveniles $(n=46)$} \\
\hline & No. & No. $(\%)$ & Vol & Vol $\%$ & $\mathrm{~F}$ & No. & No. $(\%)$ & Vol & $\mathrm{Vol} \%$ & $\mathrm{~F}$ & No. & No. $(\%)$ & Vol & $\mathrm{Vol} \%$ & $\mathrm{~F}$ \\
\hline $\begin{array}{l}\text { Hymenoptera } \\
\text { (Formicidae, } \\
\text { Apidae, } \\
\text { Apocrita) }\end{array}$ & 3578 & 94.43 & 13322.60 & 27.71 & 29 & 3736 & 93.00 & 14064.50 & 18.68 & 41 & 2434 & 95.71 & 3779.60 & 15.20 & 45 \\
\hline Coleoptera & 169 & 4.46 & 12471.00 & 25.94 & 34 & 160 & 3.98 & 26915.00 & 35.74 & 41 & 77 & 3.03 & 5881.00 & 23.65 & 32 \\
\hline $\begin{array}{c}\text { Orthoptera } \\
\text { (Caelifera, } \\
\text { Ensifera) }\end{array}$ & 11 & 0.29 & 15444.00 & 32.13 & 8 & 9 & 0.22 & 12636.00 & 16.78 & 6 & 6 & 0.24 & 8424.00 & 33.88 & 6 \\
\hline $\begin{array}{l}\text { Isoptera } \\
\text { Termitidae }\end{array}$ & 0 & 0.00 & 0.00 & 0.00 & 0 & 80 & 1.99 & 12696.70 & 16.86 & 2 & 0 & 0.00 & 0.00 & 0.00 & 0 \\
\hline Hemiptera & 2 & 0.05 & 802.64 & 1.67 & 2 & 10 & 0.25 & 4010.32 & 5.33 & 6 & 6 & 0.24 & 2407.92 & 9.68 & 6 \\
\hline $\begin{array}{l}\text { Lepidoptera } \\
\text { Larvae } \\
\text { (unidentified) }\end{array}$ & 25 & 0.66 & 4600.20 & 9.57 & 9 & 17 & 0.42 & 3128.30 & 4.15 & 10 & 16 & 0.63 & 2944.00 & 11.84 & 12 \\
\hline $\begin{array}{l}\text { Mantodea } \\
\text { (unidentified) }\end{array}$ & 1 & 0.03 & 326.50 & 0.68 & 1 & 0 & 0.00 & 0.00 & 0.00 & 0 & 0 & 0.00 & 0.00 & 0.00 & 0 \\
\hline $\begin{array}{l}\text { Phasmatodea } \\
\text { (unidentified) }\end{array}$ & 0 & 0.00 & 0.00 & 0.00 & 0 & 0 & 0.00 & 0.00 & 0.00 & 0 & 1 & 0.04 & 326.00 & 1.31 & 1 \\
\hline Chilopoda & 0 & 0.00 & 0.00 & 0.00 & 0 & 1 & 0.02 & 376.20 & 0.05 & 1 & 0 & 0.00 & 0.00 & 0.00 & 0 \\
\hline Diplopoda & 3 & 0.08 & 1104.10 & 2.30 & 3 & 4 & 0.10 & 1472.00 & 1.95 & 4 & 3 & 0.12 & 1104.00 & 4.44 & 3 \\
\hline Total & 3789 & 100.00 & 48071.04 & 100.00 & & 4017 & 100.00 & 75299.02 & 100.00 & & 2543 & 100.00 & 24866.52 & 100.00 & \\
\hline
\end{tabular}

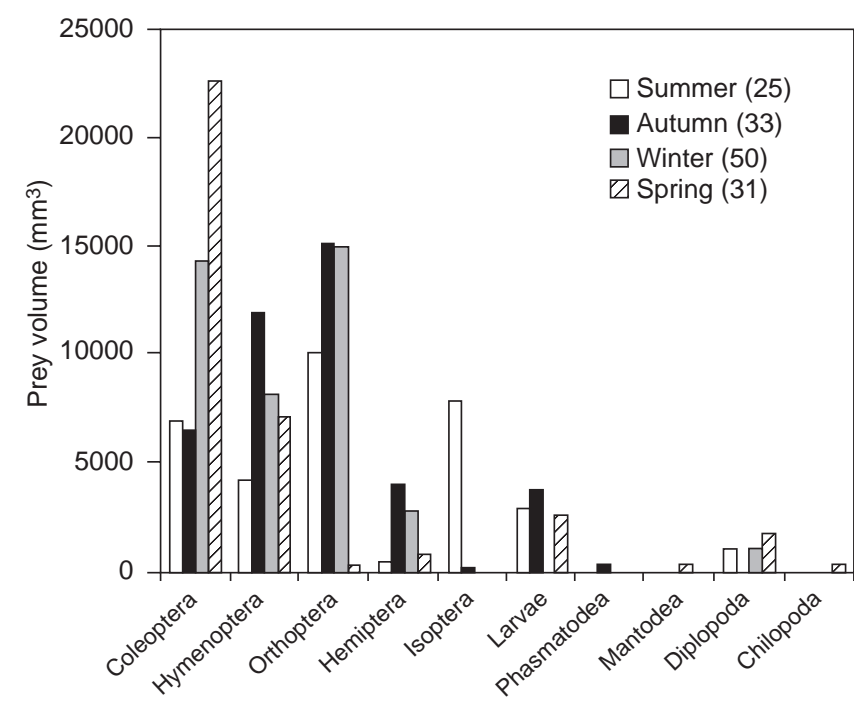

Fig. 4. Seasonal variation on prey volume found in gut contents of Acanthocerus a. atricollis. Sample sizes are indicated in parentheses. dropped drastically during the spring months. During the summer months, termite consumption (by volume) increased, and orthopteran consumption remained high. Hymenopteran consumption was lowest during the summer months (Fig. 4). Numerically, hymenopterans continued to dominate the diet during all seasons (Table 4).

\section{Foraging mode and behaviour}

Descriptive statistics for number of prey capture attempts per minute (PCA), MPM, and PTM are given in Table 5. There were no significant differences in MPM $\left(U_{8,11}=36.5, P=0.54\right)$ and PTM $\left(U_{8,11}=39.5, P=0.71\right)$ between males and females. Therefore, the data for males and females were pooled. Adults spent little time moving and moved infrequently (Table 5). The rate of prey capture attempts did not differ between males and females $\left(U_{8,11}=21.5, P=0.06\right.$; Table 5).

While stationary, adults also spent significantly $(Z=3.75, P=0.0002)$ more time in trees $(76.5 \%)$ than on the ground $(23.4 \%)$, but showed no evidence of intersexual microhabitat partitioning $(H=3.32$, 
Table 4. Seasonal variation of prey number found in gut contents of Acanthocercus a. atricollis. No. represents the total number of prey found in stomachs and No. (\%) represents the percentage of each prey taxon consumed. Sample sizes are shown in parentheses

\begin{tabular}{|c|c|c|c|c|c|c|c|c|}
\hline \multirow[b]{2}{*}{ Prey category } & \multicolumn{2}{|c|}{$\begin{array}{c}\text { Spring } \\
(n=31)\end{array}$} & \multicolumn{2}{|c|}{$\begin{array}{c}\text { Summer } \\
(n=25)\end{array}$} & \multicolumn{2}{|c|}{$\begin{array}{c}\text { Autumn } \\
(n=33)\end{array}$} & \multicolumn{2}{|c|}{$\begin{array}{l}\text { Winter } \\
(n=50)\end{array}$} \\
\hline & No. & No $\%$ & No. & No $\%$ & No. & No $\%$ & No. & No $\%$ \\
\hline \multicolumn{9}{|l|}{ Hymenoptera } \\
\hline Coleoptera & 91 & 4.80 & 139 & 10.40 & 92 & 2.50 & 106 & 3.10 \\
\hline Orthoptera & 1 & 0.05 & 4 & 0.30 & 6 & 0.20 & 14 & 0.40 \\
\hline Isoptera & 0 & 0.00 & 50 & 3.70 & 1 & 0.03 & 30 & 0.90 \\
\hline Hemiptera & 2 & 0.11 & 1 & 0.07 & 10 & 0.30 & 8 & 0.20 \\
\hline \multicolumn{9}{|l|}{ Larvae } \\
\hline (beetles, Lepidoptera) & 12 & 0.60 & 12 & 0.90 & 20 & 0.60 & 16 & 0.50 \\
\hline Mantodea & 0 & 0.00 & 0 & 0.00 & 0 & 0.00 & 1 & 0.03 \\
\hline Phasmatodea & 0 & 0.00 & 0 & 0.00 & 1 & 0.03 & 0 & 0.00 \\
\hline Chilopoda & 1 & 0.05 & 0 & 0.00 & 0 & 0.00 & 0 & 0.00 \\
\hline Diplopoda & 5 & 0.30 & 3 & 0.20 & 0 & 0.00 & 3 & 0.10 \\
\hline Total & 1892 & & 1337 & & 3612 & & 3439 & \\
\hline
\end{tabular}

Table 5. Descriptive statistics (mean \pm SE) for number of prey capture attempts, moves per minute (MPM) and percent time moving (PTM) for adult male and female Acanthocercus a. atricollis. The number of individuals for which we collected foraging data using focal animals sampling is given by $n$

\begin{tabular}{llll}
\hline Group & PCA & MPM & PTM \\
\hline Males $(n=8)$ & $0.094(0.044)$ & $0.348(0.068)$ & $4.23(0.82)$ \\
$\begin{array}{l}\text { Females }(n=11) \\
\text { Sexes combined } \\
(n=19)\end{array}$ & $0.235(0.069)$ & $0.370(0.042)$ & $3.38(0.68)$ \\
& $0.176(0.046)$ & $0.361(0.037)$ & $4.00(0.516)$ \\
\hline
\end{tabular}

$P=0.65, n=57)$, although females spent $10 \%$ more time on the ground compared to males (Table 6). When using trees, both males and females spent more time in the crown (sexes combined $=42 \%$ ) of the tree, when compared to the main trunk (sexes combined $=35 \%$ ), although this difference was not significantly different $(Z=0.54, P=0.59)$.

Focal sampling showed differences in lizard body orientation (facing up, down or horizontally) while stationary. Of the three recorded positions, both males $\left(\chi_{2}^{2}=116.73, P<0.00001\right)$ and females $\left(\chi_{2}^{2}=117.46\right.$, $P<0.00001)$ spent $>80 \%$ of their time facing up the main trunk of the tree. However, there was a significant difference between males and females in the time spent in the three position $\left(\chi_{2}^{2}=8.03, P<0.025\right)$; females spent more time than males in a horizontal position $(10.6 \%)$, while males spent more time facing down the main trunk (13.5\%; Table 6).

\section{DISCUSSION}

\section{Reproduction}

Females reached sexual maturity at $96 \mathrm{~mm}$ SVL and males at $82 \mathrm{~mm} \mathrm{SVL}$, which is similar to those reported for other agama species of similar size (Agama impalearis, Znari \& Mouden, 1997; Agama s. stellio,
Loumbourdis \& Kattoulas, 1982). Acanthocercus a. atricollis is a summer breeder; reproduction begins in late August and continues to December, with females containing oviductal eggs during late spring and early summer (wet season). No females contained oviductal and vitellogenic eggs simultaneously, suggesting that females produce one clutch per season. Other agamas have been reported to produce one to two clutches (e.g. Agama impalearis, Znari \& Mouden, 1997) and some as high as two to three clutches per year (e.g. Agama atra, Van Wyk, 1983). Male testicular volume coincided with female follicle volume, indicating that they have synchronized reproductive cycles.

Acanthocercus a. atricollis conforms to the classic lizard life-history model of a species exhibiting coevolved traits, including tank-like morphology, high clutch volume, and an ambush foraging strategy (Huey \& Pianka, 1981). Clutch size increased with body size (SVL), which is common among lizards that do not have a genetically fixed clutch size (Dunham, Miles \& Reznick, 1988). There was however, considerable variation in clutch size among females of similar SVL (Fig. 2a). This may reflect a phenotypically plastic response in reproductive allocation, in response to food availability (Vitt \& Carvalho, 1992).

\section{Diet and foraging mode}

Acanthocercus a. atricollis feed primarily on insects, ingesting the occasional millipede and centipede. Ants and beetles dominated the diet numerically, although orthopterans made up an important component of the diet volumetrically for adults. Although tree agamas have relatively large heads, no small vertebrates were found among the gut contents. There was seasonal variation in prey selection. Beetles made the largest volumetric contribution in spring, while hymenopteran (of which ants make up 90\%) and orthopteran intake increased during the autumn and winter months. 
Table 6. Proportion of time ( $\%)$ spent in the three microhabitats ( $n=8$ males, $n=11$ females) and the three body orientations ( $n=6$ males, $n=7$ females) for Acanthocercus a. atricollis. Standard errors are shown in parentheses

\begin{tabular}{|c|c|c|c|c|c|c|}
\hline \multirow[b]{2}{*}{ Sex } & \multicolumn{3}{|c|}{ Habitat use by lizards } & \multicolumn{3}{|c|}{ Lizard body orientation } \\
\hline & Ground & Main trunk & Lateral branches & Facing up & Facing down & Facing horizontal \\
\hline Males & $17.3(9.08)$ & $38.8(6.08)$ & $43.8(11.91)$ & $83.8(6.89)$ & $13.5(5.24)$ & $2.4(2.43)$ \\
\hline Females & $27.8(11.51)$ & $31.8(12.00)$ & $40.3(13.11)$ & $84.3(8.87)$ & $5.1(3.61)$ & $10.6(7.62)$ \\
\hline $\begin{array}{l}\text { Sexes } \\
\quad \text { combined }\end{array}$ & $23.4(7.59)$ & $34.7(7.02)$ & 41.8 (8.87) & $84.1(5.51)$ & $9.0(3.20)$ & $6.8(4.26)$ \\
\hline
\end{tabular}

Acanthocercus a. atricollis clearly forage throughout the year and seasonal variation in diet may be caused by seasonal differences in insect abundance. Although there was an assortment of prey items found in gut contents, the consistency of the major prey items (ants and beetles) among seasons suggests that $A$. a. atricollis has a degree of diet specialization, and feed opportunistically only when other taxa are abundant.

Insectivorous agamines are widely believed to be ambush foragers, although most have been characterized using qualitative observation. Two species of agama, Agama atra and A. planiceps, have been classified as ambush foragers using quantitative measurements (Cooper, Whiting, van Wyk \& Mouton, 1999). The low values of both MPM and PTM from the field study confirm that $A$. a. atricollis are ambush foragers, although the mean PTM and MPM values for A. a. atricollis are higher than those for $A$. atra and A. planiceps (Cooper, Whiting, van Wyk \& Mouton, 1999). Ambush foragers have typically lower MPM and PTM than active foragers (Cooper, Whiting, van Wyk \& Mouton, 1999), although some ambush foragers have been shown to move relatively frequently (e.g. Platysaurus broadleyi, Greeff \& Whiting, 2000), making a distinct criterion for MPM impossible.

A strong correlation exists between foraging mode and the use of the vomero-nasal organ to recognize prey odours (Cooper, 1995). Typical sit-and-wait foragers rely on vision for prey detection, whereas active foragers locate prey by active searching and using their welldeveloped prey chemical discrimination (Huey \& Pianka, 1981). Consequently, ambush foragers should encounter and eat more active and mobile prey, while active foragers should consume prey that is sedentary and patchily distributed (Huey \& Pianka, 1981). The prey items found in the gut of $A$. a. atricollis are mainly mobile, diurnal invertebrates, except for the occasional cricket (Ensifera) and centipede (Chilopoda), supporting the conclusion that $A$. a. atricollis is an ambush forager. The occasional nocturnal prey item may have been disturbed from its refuge (e.g. leaf litter) during the day. The occurrence of millipedes (Diplopoda) in the gut of both adult and juvenile lizards is interesting because they are known to produce toxins, and other lizards have been shown to avoid them (Vitt \& Cooper, 1986; Wapstra \& Swain, 1996). It has been suggested that the absence of prey chemical discrimination in ambush foragers may explain their opportunistic feeding of millipedes (Mouton, Geertseema \& Visagie, 2000; Van Wyk, 2000).
Active foragers can presumably detect the toxic compounds released by millipedes and therefore avoid them (Vitt \& Cooper, 1986; Wapstra \& Swain, 1996).

Both male and female $A$. a. atricollis spent the majority of their time stationary in trees, mostly in the crown. This behaviour is typical of ambush foragers, which wait motionless at ambush posts and search visually for prey (Huey \& Pianka, 1981). However, one would expect that the prime ambush position for arboreal lizards would be facing down the tree to scan the ground. Acanthocercus a. atricollis spent $>80 \%$ of the time facing up the trunk of the tree. This suggests that $A$. a. atricollis may be concentrating on prey on the branches within the crown of the tree. This is further supported by the presence of arboreal insects in their diet (Ledger, 1979; H. Robertson, pers. comm.).

\section{Evolution of sexual size dimorphism}

There was no significant sexual dimorphism in body size between male and female $A$. a . atricollis, although adult males were the largest individuals among the specimens examined. However, head size differed considerably, with adult males having longer and wider heads than adult females. Two hypotheses are most commonly used to explain the evolution of sexual dimorphism in head size: sexual selection (male-male competition and/or female choice; Harvey \& Bradbury, 1993) or partitioning of food on the basis of sexual differences in feeding behaviour (intraspecific niche divergence hypothesis; Shine, 1989, 1991). A third hypothesis, food limitation, may also explain sexual dimorphism but can only be examined in wild populations (e.g. Censky, 1996). In A. a. atricollis, we favour the sexual selection hypothesis over the intraspecific niche divergence hypothesis because there were few trophic differences between the sexes. The selection of prey by male and female agamas was similar both numerically and volumetrically. Also, the lack of a correlation between SVL and gape size and two measures of prey size (mean prey volume and largest prey item) suggests that body size does not influence prey size selection in any significant way. There was also no evidence of intersexual microhabitat partitioning. Both sexes used the same trees and in a similar fashion (L. T. Reaney \& M. J. Whiting, pers. obs.). Sexual selection is often favoured as an explanation for sexual dimorphism in head size when male mating success correlates positively with head size, 
thereby favouring larger males during male-male contests (Bull \& Pamula, 1996; Znari \& Mouden, 1997; Randriamahazo, 2000). Like other agamas (e.g. AlJohany, 1995; Znari \& Mouden, 1997), A. a. atricollis males observed in the field were highly territorial and engaged in agonistic interactions (sometimes involving biting) with rival males. Males also frequently signalled with assertion displays. Furthermore, to the human observer, agamas are sexually dichromatic. Males have deep blue heads, while females are relatively devoid of colour. As in other animals with sexual dichromatism (see Andersson, 1994), this colour difference is probably the result of sexual selection. In summary, a lack of evidence for intersexual trophic partitioning and the presence of male combat and bright colour suggests that sexual selection may explain larger head size in males.

\section{Acknowledgements}

We thank Wulf Haacke and Marion Burger (Transvaal Museum) for the loan of specimens. We also thank Owen Sutton, manager of Mountain Sanctuary Park, for various assistance in the field, the many people who assisted with mapping trees and field work in general, Hamish Robertson for identifying the ant species, and Scott Keogh and Jonathan Webb for helpful comments on an earlier version of the manuscript. This study was funded by a University Research Committee grant to MJW from the University of the Witwatersrand. Clearance for this study was granted by the University of the Witwatersrand Animal Ethics Committee (clearance certificate number: 2000-86-2a). Permission to conduct the field study was granted by the Northwest Province Parks Board (permit number: 833/2000 NW).

\section{REFERENCES}

Al-Johany, A. M. (1995). The ecology of Agama yemenesis Klausewitz (Lacertilia: Agamidae) in south-western Arabia. $J$. arid Environ. 29: 495-503.

Analytical Software. (1996). Statistix for Windows. Tallahassee: Analytical Software.

Anderson, R. A. \& Karasov, W. H. (1981). Contrasts in energy intake and expenditure in sit-and-wait and widely foraging lizards. Oecologia (Berl.) 49: 67-72.

Andersson, M. (1994). Sexual selection. New Jersey: Princeton University Press.

Branch, W. R. (1998). Field guide to snakes and other reptiles of southern Africa. 3rd edn. Cape Town: Struik.

Bull, C. M. \& Pamula, Y. (1996). Sexual dimorphism in head sizes and reproductive success in the sleepy lizard Tiliqua rugusa. $J$. Zool. (Lond.) 240: 511-521.

Censky, E. J. (1996). The evolution of sexual size dimorphism in the teiid lizard Ameiva plei: a test of alternative hypotheses. In Contributions to West Indian herpetology: a tribute to Albert Schwartz: 277-289. Powell, R. \& Henderson, R. W. (Eds). Ithaca: Society for the Study of Amphibians and Reptiles.

Cooper, W. E. Jr (1995). Foraging mode, prey chemical discrimination, and phylogeny in lizards. Anim. Behav. 50: 973-985.

Cooper, W. E. Jr, Vitt, L. J., Hedges, R. \& Huey, R. B. (1990).
Locomotor impairment and defense in gravid lizards (Eumeces laticeps): behavioural shifts in activity may offset costs of reproduction in an active forager. Behav. Ecol. Sociobiol. 27: $153-157$.

Cooper, W. E. Jr, Whiting, M. J. \& van Wyk, J. H. (1997). Foraging modes of cordyliform lizards. S. Afr. J. Zool. 32: 913.

Cooper, W. E. Jr, Whiting, M. J., van Wyk, J. H. \& Mouton, P. le F. N. (1999). Movement- and attack-based indices of foraging mode and ambush foraging in some gekkonid and agamine lizards from southern Africa. Amphib.-Reptilia 20: 391-399.

Dunham, A. E., Miles, D. B. \& Reznick, D. N. (1988). Life history patterns in squamate reptiles. In Biology of the Reptilia 16. Ecology B. Defense and life history: 441-522. Gans, C. \& Huey, R. B. (Eds). New York: Alan R. Liss.

Flemming, A. F. \& Mouton, P. le F. N. (2000). Geographical variation in sexual size dimorphism in the rock agama, Agama atra (Sauria: Agamidae). Afr. Zool. 35: 233-249.

Greeff, J. M. \& Whiting, M. J. (2000). Foraging-mode plasticity in the lizard Platysaurus broadleyi. Herpetologica 56: 402-407.

Harvey, P. H. \& Bradbury, J. W. (1993). Sexual selection. In: Behavioural ecology: an evolutionary approach: 203-233. 3rd edn. Krebs, J. R. \& Davies. N. B. (Eds). Oxford: Blackwell Scientific.

Heideman, N. J. L. (1994). Reproduction in Agama aculeate aculeate and Agama planiceps planiceps females from Windhoek, Namibia. Amphib.-Reptilia 15: 351-361.

Huey, R. B. \& Pianka, E. R. (1981). Ecological consequences of foraging mode. Ecology 62: 991-999.

Huey, R. B., Pianka, E. R. \& Schoener, T. W. (Eds) (1983). Lizard ecology: studies of a model organism. Cambridge: Harvard University Press.

Ledger, J. (1979). SH Skaife: African insect life. 2nd edn. London: Country Life Books.

Losos, J. B. (1990). Concordant evolution of locomotor behaviour, display rate and morphology in Anolis lizard. Anim. Behav. 39: 879-890.

Losos, J. B., Jackman, T. R., Larson, A., de Queiroz, K. \& Rodríguez-Schettino, L. (1998). Contingency and determinism in replicated adaptive radiations of island lizards. Science 279: $2115-2118$

Losos, J. B., Warheit, K. I. \& Schoener, T. W. (1997). Adaptive differentiation following experimental island colonisation in Anolis lizards. Nature (Lond.) 387: 70-73.

Loumbourdis, N. S. \& Kattoulas, M. S. (1982). Ovarian cycle of the lizard Agama stellio stellio. Amphib.-Reptilia 2: 343-348.

Milstead, W. W. (Ed.) (1967). Lizard ecology: a symposium. Columbia: University of Missouri Press.

Mouton, P. le F. N., Geertsema, H. \& Visagie, L. (2000). Foraging mode of a group-living lizard, Cordylus cataphractus (Cordylidae). Afr. Zool. 35: 1-7.

Mouton, P. le F. N. \& van Wyk, J. H. (1997). Ecophysiological character evolution in cordyliform lizards: an overview. Afr. J. Herpetol. 46: 78-88.

Perry, G. (1995). The evolutionary ecology of lizard foraging: a comparative study. $\mathrm{PhD}$ thesis, University of Texas.

Pianka, E. R. (1986). Ecology and natural history of desert lizards. New Jersey: Princeton University Press.

Randriamahazo, H. J. A. R. (2000). Sexual size dimorphism in the lizard Oplurus cuvieri cuvieri (Squamata, Opluridae) from Madagascar. Afr. Zool. 35: 287-293.

Shine, R. (1989). Ecological causes for the evolution of sexual dimorphism: a review of the evidence. Q. Rev. Biol. 64: 419461.

Shine, R. (1991). Intersexual dietary divergence and the evolution of sexual dimorphism in snakes. Am. Nat. 138: 103-122.

Sinervo, B. \& Huey, R. B. (1990). Allometric engineering: an experimental test of the causes of interpopulational differences in performance. Science 248: 1106-1109. 
Sinervo, B. \& Licht, P. (1991). Proximate constraints on the evolution of egg size, egg number, and total clutch mass in lizards. Science 252: 1300-1302.

Simpson, E. H. (1949). Measurement of diversity. Nature (Lond.) 163: 688 .

van Wyk, J. H. (1983). Seasonal breeding in the female rock lizard, Agama atra (Sauria: Agamidae) in the south western Cape Province with special reference to possible environmental controlling factors. Navors. nas. Mus., Bloemfontein 4: 193 208.

van Wyk, J. H. (1984a). Ovarian morphological changes during the annual breeding cycle of the rock lizard Agama atra (Sauria: Agamidae). Navors. nas. Mus., Bloemfontein 4: 237275.

van Wyk, J. H. (1984b). Physiological changes during the ovarian cycle of the female rock lizard, Agama atra (Sauria: Agamidae). S. Afr. J. Zool. 19: 253-260.

van Wyk, J. H. (1992). Life history and physiological ecology of the lizard, Cordylus giganteus. $\mathrm{PhD}$ thesis, University of Cape Town.

van Wyk, J. H. (2000). Seasonal variation in stomach contents and diet composition in the large girdled lizard, Cordylus giganteus (Reptile: Cordylidae) in the Highveld grasslands of the northeastern Free State, South Africa. Afr. Zool. 35: 927.

Vitt, L. J. (1995). The ecology of tropical lizards in the Caatinga of northeast Brazil. Occas. Pap. Okla. Mus. Nat. His. 1: 1-29.

Vitt, L. J. \& Caldwell, J. P. (1994). Resource utilization and guild structure of small vertebrates in the Amazon forest leaf litter. $J$. Zool. (Lond.) 234: 463-476.

Vitt, L. J. \& Cooper, W. E. (1986). Foraging and diet of a diurnal predator (Eumeces laticeps) feeding on hidden prey. J. Herpetol. 20: $208-415$.

Vitt, L. J. \& de Carvalho, C. M. (1992). Life in the trees: the ecology and life history of Kentropyx striatus (Teiidae) in the lavrado area of Roraima, Brazil, with comments on the life history of tropical teiid lizards. Can. J. Zool. 70: 1995-2006.

Vitt, L. J. \& Pianka, E. R., (Eds). (1994). Lizard ecology: historical and experimental perspectives. New Jersey: Princeton University Press.

Vitt, L. J. \& Zani, P. A. (1996). Organization of a taxonomically diverse lizard assemblage in Amazonian Ecuador. Can. J. Zool. 74: 1313-1335.

Vitt, L. J., Zani, P. A., Caldwell, J. P. \& Durtsche, R. D. (1993). Ecology of the whiptail lizard Cnemidophorus deppii on a tropical beach. Can. J. Zool. 71: 2391-2400.

Waltner, R. C. (1991). Altitudinal ecology of Agama tuberculata Gray in the western Himalayas. Univ. Kans. Mus. nat. Hist. Misc. Publ. 83: 1-74.

Wapstra, E. \& Swain, R. (1996). Feeding ecology of the Tasmanian skink, Niveoscincus ocellatus (Squamata: Scincidae). Austr. J. Zool. 44: 205-213.

Znari, M. \& Mouden, E. H. E. (1997). Sexual dimorphism, reproduction and fat body cycles in bibron's agama (Agama impalearis, Boettger, 1874) (Sauria: Agamidae). Herpetologica 53: 411-422. 